\title{
KOMPARATIVNA ANALIZA NACIONALNOG OBAVEŠTAJNO-BEZBEDNOSNOG SISTEMA REPUBLIKE SRBIJE I REPUBLIKE MAĐARSKE
}

\author{
Stanimir Đukić \\ Univerzitet „Union - Nikola Tesla“, Fakultet za diplomatiju i bezbednost \\ Nenad M. Avramović \\ Univerziteta Privredna akademija Novi Sad, \\ Pravni fakultet za privredu i pravosuđe
}

\begin{abstract}
Iradu se razmatra nacionalna bezbednost i Strategija nacionalne bezbednosti, kojom se potvrđuje privrženost Republike Srbije opštim demokratskim vrednostima, međunarodnom pravu i poštovanju sopstvene državotvorne tradicije. Pojmovno se definišu obaveštajno-bezbednosni sistem države, mesto, uloga i zadaci kao elementi nacionalne bezbednosti. Osim toga, detaljnije i studioznije se razmatraju obaveštajnobezbednosni sistemi Republike Srbije i Republike Mađarske u pogledu normativnopravne i organizacione sličnosti i razlika.
\end{abstract}

Ključne reči: nacionalna bezbednost, bezbednost, obaveštajno-bezbednosni sistem, službe bezbednosti, Bezbednosno-informativna agencija, Vojnobezbednosna agencija, Vojnoobaveštajna agencija, Republika Srbija, Republika Mađarska

\section{Uvod}

Analizirajući savremeni svet, uočava se, da se u njemu više od dvadeset pet godina dešava nekoliko bitnih procesa. Možemo reći da se paralelno odvijaju procesi, kao što su: globalizacija, novi svetski poredak, tranzicija, nova pravila međunarodnih odnosa, novo shvatanje bezbednosti i drugo. S tim u vezi, svaki od njih, sam za sebe, i svi zajedno, podrazumevaju suštinske promene u sferi razvoja većine država u svetu. Tako čovečanstvo, a u okviru njega države, sve više zavise od odnosa koji vladaju unutar navedenih procesa. To praktično znači, da je danas teško zamisliti državu, koja dobro funkcioniše, a da je izvan ovih tokova. Pojednostavljeno rečeno, ko nije uklopljen u svetski sistem, ne može ni opstati. Takođe, problem nastaje zato što u izgradnji tog „novog sistema“ postoje strukturni problemi čije se jedinstveno rešenje ne nazire, pa se oni rešavaju od slučaja do slučaja, po principu ko je jači.

Kada se govori o ukupnoj bezbednosti, nju treba shvatiti kao uslov opstanka i razvoja (države, društva, nacije, ljudi i živog sveta na planeti). Ona sama po sebi ništa ne stvara (naročito ne materijalna dobra), već samo omogućava život, zdravlje, slobodu, pa i stvaranje materijalnih dobara. Bezbednost je jedan od fundamentalnih uslova za postojanje svake društvene zajednice, a samim tim i države. Bez odgovarajućeg nivoa bezbednosti ne možemo govoriti o suverenosti, demokratskoj vladavini, ni o stabilnosti društva i drža- 
ve u celini. Zbog toga, svaka država ima svoj sistem bezbednosti, odnosno obaveštajnobezbednosni sistem, svoje institucije, snage i službe bezbednosti, koji je štite iznutra i spolja, radi prevencije i represije, odnosno eventualnog delovanja.

Pojam nacionalna bezbednost se češće nego drugi pojmovi upotrebljava u literaturi. Pod ovim pojmom se uglavnom podrazumeva željeno stanje zaštićenosti države, koje se postiže eliminisanjem pretnji i rizika po vitalne vrednosti države. S tim u vezi, bezbednost podrazumeva stanje u kome država smatra da joj ne preti neka vrsta vojnog napada, neki oblik političkog pritiska i ekonomsko ugrožavanje izvan granica zemlje, odnosno, neka vrsta napada ili pritiska iznutra, kao što je: ideološki, ekonomski, verski, ili ekstremno politički, koji usporava da se država nesmetano razvija kako sama, tako i zajedno sa drugim državama.

Postojanje različitih izvora ugrožavanja bezbednosti čoveka, njegove životne sredine i društva, uopšte nameće obavezu državi da organizuje sistem bezbednosti koji će štititi njen suverenitet i omogućiti nesmetan razvoj svih njenih kapaciteta, u skladu sa savremenim, demokratskim tekovinama modernog društva. U praksi, većina zemalja razvija sopstveni sistem bezbednosti, ali istovremeno teže pristupanju postojećim savezima, unijama i drugo, kako bi obezbedile nesmetan društveni razvoj i umanjile uticaje bezbednosnih pretnji.

Opredeljenje Republike Srbije za pristupanje Evropskoj uniji, nametnulo je obavezu usklađivanja postojeće normativno-pravne regulative sa pravnim aktima Unije, reformu državne uprave i druge reforme. U sklopu reformi koje su obeležile prethodne godine, obaveštajno-bezbednosni sistem Republike Srbije, takođe je pretrpeo značajne izmene, kako normativne, tako i organizacijsko-funkcionalne. Reforma sektora bezbednosti, posebno obaveštajno-bezbednosnog sistema, podrazumevala je uređenje po standardima modernog i demokratskog društva.

S tim u vezi, treba naglasiti da je Republika Srbija, kao multietnička i multikulturalna država, po svojim specifičnostima u odnosu na izazove, rizike i pretnje, teško uporediva sa drugim državama članicama EU (posebno sa državama iz regiona), pa se nameće potreba da svoj put u članstvo u Evropskoj uniji, traži na poseban, drugačiji način, u odnosu na države koje su do sada pristupile Uniji. Tačnije rečeno, teško je porediti način pristupanja Republike Srbije u EU sa načinom pristupanja većine članica Unije, koje su postale punopravan član EU, odnosno Republika Srbija teško može da primeni identičan model u procesu pristupanja EU.

U radu je prikazana komparativna analiza obaveštajno-bezbednosnog sistema Republike Srbije i Republike Mađarske, susednom državom sa kojom se graniči, koja je već članica EU, koja je približno iste veličine, i koja ima iste ili slične bezbednosne izazove, rizike i pretnje. Osim toga, sličnost između ove dve države ogleda se i u tome, što su sve do početka devedesetih godina prošlog veka, bile obe socijalističkog društvenog uređenja, u kojem je jak faktor očuvanja i kontrolisanja vlasti bio upravo obaveštajno-bezbednosni sistem.

\section{Nacionalna bezbednost}

Nacionalna bezbednost je pojam koji se češće nego drugi objašnjava u našoj literaturi. Pod njim se podrazumeva željeno stanje zaštićenosti države koje se postiže eliminisanjem pretnji i rizika po vitalne vrednosti države. Iz toga proističe da je to višeznačajan pojam koji u najopštijem smislu predstavlja stanje u kome država smatra da joj ne preti vojni napad, politički pritisak ili ekonomsko ugrožavanje spolja, kao ni ekstremni politički, ekonomski, ideološki, verski ili kulturni atak iznutra, tako da država može normalno da se razvija samostalno ili u zajednici sa drugim državama (Đukić, 2018:5). 
Sam pojam nacionalna bezbednost nalazi se u upotrebi od 1943. godine, kada je Valter Lipman (Walter Lipman) u svom delu "U.S. Foreign Policy" prvi put upotrebio taj termin. Posle Drugog svetskog rata ovaj pojam je našao široku primenu u političkom rečniku savremenih država. $U$ tom kontekstu on je upotrebljavan da označi unutrašnju i spoljnu bezbednost države, odnosno bezbednost države u odnosu na spoljne i unutrašnje izvore ugroženosti. Radi se, dakle, o nacionalnoj bezbednosti jedne države koja obezbeđuje opstanak i normalno delovanje države sa svim elementima njene nezavisnosti, teritorijalne celovitosti i ustavnog poretka (Stajić, 2011:33).

Kada je u pitanju ostvarivanje nacionalne bezbednosti, neophodna su najčešće dva uslova, i to: 1) državni cilj, koji podrazumeva nacionalne vrednosti izražene u najvišim dokumentima države (prvenstveno Ustavu), odnosno u Strategiji nacionalne bezbednosti, i 2) struktura elemenata, snaga, aktivnosti i funkcija usmerenih ka ostvarivanju glavnog cilja (strategija nacionalne bezbednosti).

Iz navedenog se može zaključiti da je strategija nacionalne bezbednosti uslov, osnov, usmeravajući i korektivni dokument jedne države (društva), nastao kao izraz uvažavanja opšteprihvaćenih standarda bezbednosnog organizovanja savremenih država. To je ujedno i dokument projekcije razvoja i funkcionisanja sistema bezbednosti u budućnosti.

Osim toga, možemo sasvim sigurno reći da je, strategija nacionalne bezbednosti ujedno i poruka drugim međunarodnim i unutrašnjim činiocima šta država svrstava u svoje vitalne vrednosti neophodne za opstanak, rast i razvoj, a koje će braniti svojom ukupnom moći, čiji je sistem bezbednosti najznačajniji deo. Drugim rečima, u strategiju nacionalne bezbednosti je utkana crvena linija ispod koje država neće i ne može ići u odbrani svojih interesa (Stajić, 2011:306).

Kada govorimo o Strategiji nacionalne bezbednosti Republike Srbije, ona predstavlja najvažniji strateški dokument kojim se utvrđuju osnove politike bezbednosti u zaštiti nacionalnih interesa Republike Srbije. S tim u vezi, polazište Strategije nacionalne bezbednosti čine: suverenitet i teritorijalni integritet Republike Srbije; ekonomski prosperitet; socijalna stabilnost; razvoj demokratije i vladavina prava; poštovanje ljudskih i manjinskih prava; evropska spoljnopolitička orijentacija i unapređenje saradnje sa najuticajnijim subjektima međunarodne zajednice i državama u regionu.

Takođe, Strategija nacionalne bezbednosti potvrđuje privrženost Republike Srbije opštim demokratskim vrednostima, međunarodnom pravu i poštovanju sopstvene državotvorne tradicije. Opredeljenja iskazana u Strategiji nacionalne bezbednosti izražavaju spremnost Republike Srbije da u okviru Organizacije ujedinjenih nacija, evropskih i drugih međunarodnih organizacija i regionalnih struktura, doprinosi izgradnji i unapređenju sopstvene, regionalne i globalne bezbednosti.

\section{Pojmovno definisanje obaveštajno-bezbednosnog sistema države}

Kada se uopšte govori o obaveštajno-bezbednosnom sistemu jedne države, prvo se misli na svrsishodnost takvog sistema, koji se prvenstveno sastoji u efikasnoj zaštiti vitalnih državnih vrednosti od spoljnih i unutrašnjih nekonvencionalnih oblika ugrožavanja njihove bezbednosti. 
Tokom istorije, a posebno danas, država kao poseban, specifičan subjekt međunarodne zajednice, svoje vitalne vrednosti i interese čuva i razvija. Imajući u vidu evidentne bezbednosne pretnje, koje najčešće dolaze tajno, kako spolja, tako i iznutra, i zbog činjenice da su se takve pretnje uglavnom uočavale sa zakašnjenjem, odnosno kada su nastale štetne posledice po nacionalnu bezbednost, veliki broj država je uspostavio, a takođe i danas postoji, poseban sistem za efikasan odgovor na takve opasnosti i pretnje, koji se najkraće naziva obaveštajno-bezbednosnom sistem.

Ovaj po mnogo čemu specifičan i misteriozan državni sistem strukturisan je, zadužen (nadležan) i osposobljen da obezbedi državu od strategijskog iznenađenja, nezavisno od njegovih "nevidljivih“ nosilaca koji mogu da budu unutar njenih granica ili u njenom bezbednosnom okruženju. Njegovu okosnicu čine obaveštajne i bezbednosne službe države, čije efikasno funkcionisanje i rezultati presudno zavise od rukovodstva države. To je zato što rukovodstvo, uvažavanjem zakonske regulative i realnog stanja međunarodnog položaja matične zemlje, a naročito na osnovu predviđanja događaja u zemlji i njenom bezbednosnom okruženju, usmerava i rukovodi obimom, karakterom i dinamikom obaveštajno-bezbednosnog sistema, radi zaštite nacionalne bezbednosti (Mijalkovski, 2009:14).

U cilju boljeg razumevanja, nabrojaćemo važne pojmove za shvatanje obaveštajnobezbednosnog sistema države, i to:

1) Država;

2) Vitalne državne vrednosti;

3) Bezbednost, a u okviru nje: a) subjekt bezbednosti, b) objekt bezbednosti (zaštite) i c) subjekt ugrožavanja (opasnosti);

4) Nacionalna bezbednost.

$\mathrm{Na}$ osnovu gore navedenog, na sledećem grafikonu su prikazane osnovne činjenice o obaveštajno-bezbednosnom sistemu države (slika 1). 


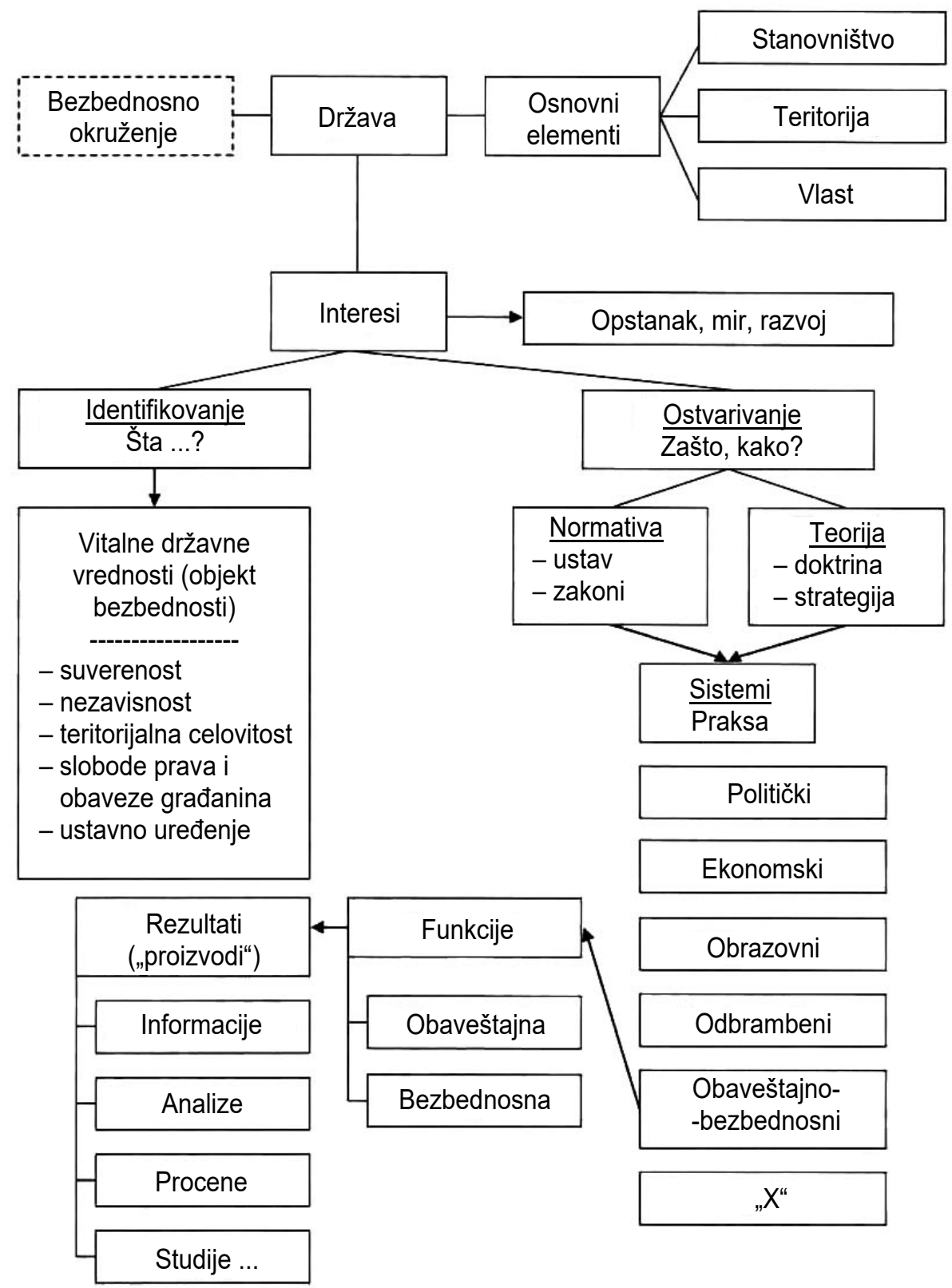

Slika 1 - Osnovne činjenice o obaveštajno-bezbednosnom sistemu države Izvor: autor (Prema: Mijalkovski, M.) 
Možemo sasvim sigurno reći da, obaveštajno-bezbednosni sistem predstavlja podsistem sistema nacionalne bezbednosti svake države, koji preduzima mere na zaštiti i suprotstavljanju ugrožavanju bezbednosti vitalnih interesa države i njenih građana.

Osim toga, postoje mnoge definicije obaveštajno-bezbednosnog sistema od različitih autora. U tom smislu, može se definisati kao sistem kojem je propisima definisan delokrug nadležnosti i međusobnih prava svih obaveštajnih i bezbednosnih službi i drugih ustanova države ili drugog odgovarajućeg entiteta koje su angažovane da prikupljaju, procenjuju i distribuiraju obaveštajne podatke, kao i da izvršavaju druge zahteve koji im se stave u nadležnost (Milošević, 2001:39). On objedinjava sve obaveštajne i bezbednosne organizacije i institucije, sredstva i metode koje oni primenjuju u obaveštajnom radu, mehanizme koordinacije i kontrole nad njima, kao i zakonsku regulativu te materije.

U savremenom međunarodnom sistemu nezamislivo je postojanje i funkcionisanje države bez obaveštajno-bezbednosnog sistema pošto on u savremenim međunarodnim odnosima predstavlja ,,oči i uši“ nacionalne bezbednosti (Dragišić, 2011:173).

Savremeni obaveštajno-bezbednosni sistem primarno se bavi „informacijom“.

O kakvim se značajnim poslovima radi, u smislu posedovanja informacije, možda najbolje ilustruju navodi Džozefa Naja: „moć informacije pripada onima koji mogu preurediti i na pravi način vrednovati informaciju kako bi izdvojili ono što je tačno i važno" (Naj Džozef, 2006:307).

Obaveštajno-bezbednosni sistem u organizaciono-funkcionalnom smislu obuhvata obaveštajnu delatnost kojim se bave obaveštajne službe i kontraobaveštajnu delatnost kojom se bave bezbednosne službe.

$\mathrm{Na}$ osnovu navedenih definicija, mogli bismo definisati obaveštajno-bezbednosni sistem kao specijalizovanu, relativno autonomnu državnu instituciju. Prema tome, on obuhvata obaveštajnu i bezbednosnu funkciju odbrane države i cilj ovog sistema je da neprekidno i pravovremeno obezbeđuje kvalitetne podatke o spoljnim i unutrašnjim nosiocima opasnosti po bezbednost vitalnih vrednosti matične države. Nosioci tih aktivnosti to uglavnom čine tajno, prate i dokumentuju protivzakonite delatnosti, izveštavaju nadležne državne organe i tela o vrstama i oblicima ugrožavanja bezbednosti i samostalno ili u saradnji sa drugim državnim institucijama otklanjaju stvarne i moguće opasnosti po bezbednost matične države.

Kada govorimo o elementima, odnosno komponentama obevaštajno-bezbednosnog sistema države, možemo slobodno reći da ga čini nekoliko zasebnih, svakako međuzavisnih celina. U najopštijem smislu, obevaštajno-bezbednosni sistem države sastoji se od dva elementa, i to: 1) rukovodeće-nadzorni i 2) operativni. Rukovodeći organ (element) obevaštajno-bezbednosnog sistema u najvećem broju država jeste predsednik države, koji ostvaruje ovaj zadatak lično ili preko posebnog tela (organa), najčešće terminološki poznatog kao Savet za nacionalnu bezbednost (SNB). Članove ovog tela određuje zakon ili predsednik države na osnovu zakona. Raspoloživa saznanja ukazuju na to da su članovi SNB-a najčešće predsednik države, premijer, ministri za unutrašnje poslove, odbranu i spoljne poslove i načelnik generalštaba. Osim njih, sednicama SNB-a uvek ili povremeno prisustvuju i neki drugi ministri i savetnici predsednika države. Prilikom razmatranja pojedinih pitanja, sednicama SNB-a prisustvuju (učestvuju u radu) i druga lica iz dotičnih oblasti (Mijalkovski, 2009:36).

$\mathrm{Na}$ sledećoj slici su grafički prikazane osnovne komponente o obaveštajno-bezbednosnom sistemu države. 


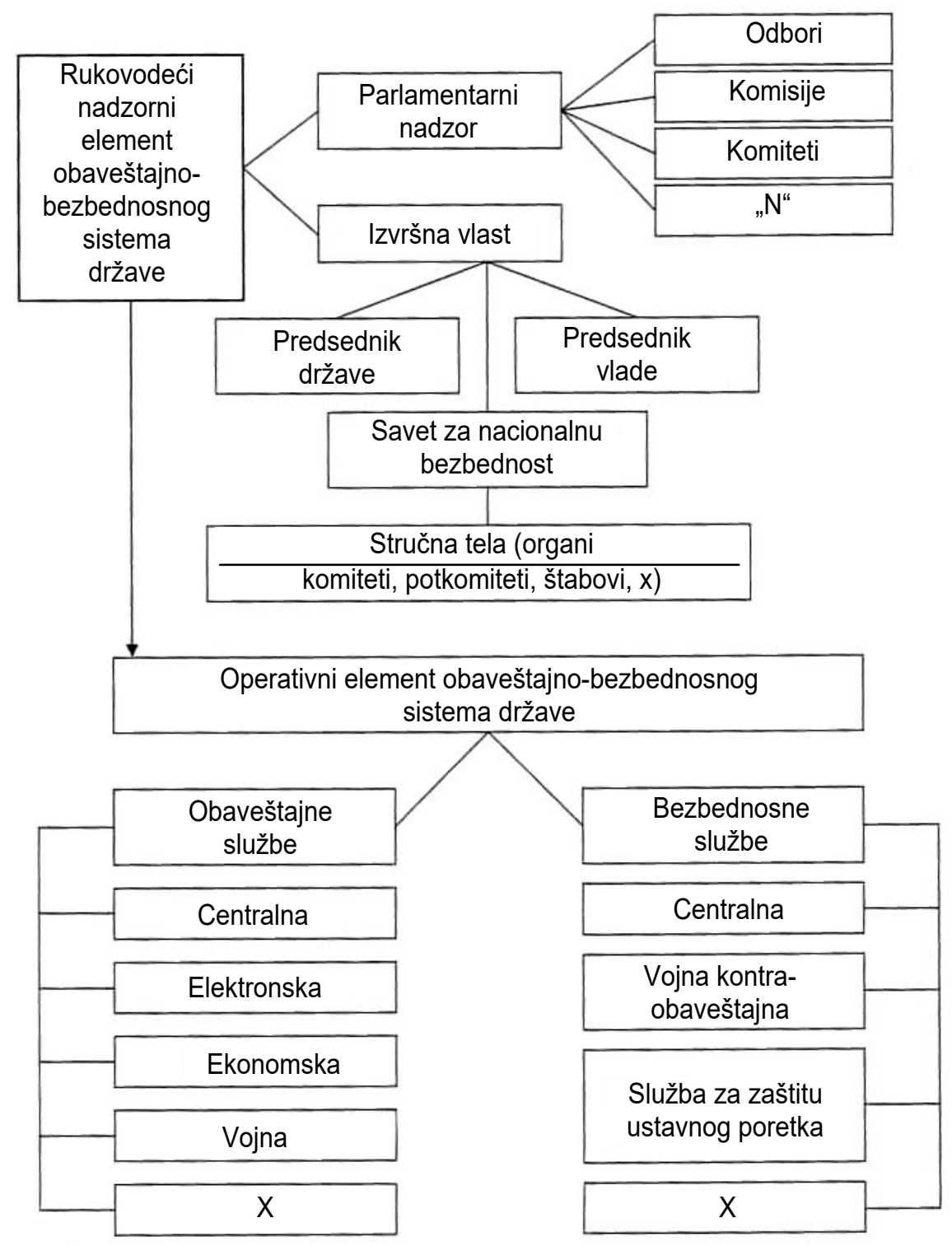

Slika 2 - Osnovne komponente o obaveštajno-bezbednosnom sistemu države Izvor: autor (Prema: Mijalkovski, M.) 


\section{Obaveštajno-bezbednosni sistem Republike Srbije}

Kada se govori o obaveštajno-bezbednosnom sistemu Republike Srbije, on ima određenu genezu razvoja, pa ćemo u najkraćim crtama hronološki izložiti određene činjenice. Naime, posle osamostaljenja Republike Srbije (u junu 2006), odnosno raspadom Državne zajednice Srbija i Crna Gora, Srbija je dobila priliku da reformiše i oblikuje sistem nacionalne bezbednosti, pa samim tim i obaveštajno-bezbednosni sistem, na sveobuhvatan i celovit način, u skladu sa svojim mogućnostima i potrebama, odnosno u skladu sa izazovima, rizicima i pretnjama.

Nakon toga, u drugoj polovini 2007. godine, Narodna skupština Republike Srbije usvojila je Zakon o osnovama uređenja službi bezbednosti Republike Srbije („Službeni glasnik RS“, broj 116/2007), kojim je učinjen značajan pomak u normativnom uređenju postojećeg obaveštajnog-bezbednosno sistema Republike Srbije. Ovim zakonom regulisani su najvažniji aspekti obaveštajno-bezbednosnog sistema Republike Srbije, i to: usmeravanje i usklađivanje rada službi bezbednosti, i nadzor nad njihovim radom. Prema ovom zakonu, obaveštajno-bezbednosni sistem Republike Srbije, čine sledeći organizacijski sastavi, i to: 1) Savet za nacionalnu bezbednost; 2) Biro za koordinaciju rada službi bezbednosti; 3) Službe bezbednosti (Bezbednosno-informativna agencija, Vojnobezbednosna agencija i Vojnoobaveštajna agencija) i 4) Odbor Narodne skupštine za nadzor nad radom službi bezbednosti.

Osim navedenog zakona, reforme su nastavljene 2009. godine, usvajanjem i stupanjem na snagu Zakona o Vojnobezbednosnoj agenciji i Vojnoobaveštajnoj agenciji. Ovaj zakon je specifičan i po tome što se prvi put javno definiše metodologija rada službi. Donošenjem zakona stvoreni su uslovi za uspostavljanje demokratske civilne kontrole i to od strane izvršne i zakonodavne vlasti.

Ovim zakonima, obaveštajno-bezbednosne službe, vojne i civilne, zakonski su uređene, kako krovnim, tako i pojedinačnim zakonima i zastupaju interese države kao samostalne i depolitizovane institucije, koje profesionalno i stručno štite državni suverenitet spolja i iznutra.

Analizirajući namenu, zadatke i funkcije obaveštajno-bezbednosnog sistema, možemo zaključiti da svoje izvorište nalazi u Ustavu Republike Srbije, donetom u oktobru 2006. godine. U ovom najvišem državnom dokumentu jasno su registrovane vitalne državne vrednosti, kao što su: opstanak i razvoj; suverenost; nezavisnost; teritorijalna celovitost; vladavina prava koja počiva na neotuđivim ljudskim pravima i ostvaruje se slobodnim i neposrednim izborima; ekonomsko uređenje zasnovano na tržišnoj privredi; teritorijalno uređenje; i ustavnost i zakonitost, kao i nadležnosti Republike Srbije radi njihove zaštite.

$\mathrm{Na}$ osnovu izvršenih procena izazova, rizika i pretnji po bezbednost Republike Srbije, sagledavaju se i zadaci i funkcije obaveštajno-bezbednosnog sistema Republike Srbije. $S$ tim u vezi, potencijalni oblici ugrožavanja mogu se razvrstati na vojne i nevojne izazove, rizike i pretnje. Kada su u pitanju vojne pretnje, u njih ubrajamo: agresije, oružane sukobe, oružane pobune i druge sporove sa upotrebom oružane sile, dok za nevojne izazove, rizike i pretnje bezbednosti, ubrajamo one koje se uglavnom ispoljavaju u obliku: terorizma, organizovanog kriminala, etničkih napetosti, nacionalnog i verskog ekstremizma, ilegalnih migracija, industrijskih i drugih nesreća i katastrofa i prirodnih nepogoda. 
Na osnovu do sada iznetog, u najkraćem možemo konstatovati da je, obaveštajnobezbednosni sistem Republike Srbije, namenjen da zaštiti njenu nacionalnu bezbednost od nosilaca ilegalnih delatnosti usmerenih na podrivanje ili uništenje Ustavom utvrđenog društvenog poretka Republike Srbije.

Za tu namenu preduzima višestruko isprepletane preventivne i reaktivne mere i aktivnosti, odnosno otkriva i prati, i u saradnji sa organima izvršne i sudske vlasti, sprečava (onemogućava) spoljne i unutrašnje nosioce da ugroze bezbednost vitalnih državnih vrednosti, odnosno nacionalnu bezbednost Republike Srbije (Mijalkovski, 2009:237).

Kada je u pitanju rukovođenje obaveštajno-bezbednosnim sistemom Republike Srbije, možemo reći da rukovođenje ovim značajnim i bitnim sistemom za nacionalnu bezbednost, ostvaruju rukovodeća tela (Savet za nacionalnu bezbednost i Biro za koordinaciju rada službi bezbednosti), kao i pojedinci odnosno direktori službi bezbednosti, njihovi zamenici, pomoćnici i dr. U skladu sa Zakonom o osnovama uređenja službi bezbednosti Republike Srbije, Savet za nacionalnu bezbednost je telo Republike Srbije, koje obavlja određene poslove i zadatke iz oblasti nacionalne bezbednosti. Savet se stara o nacionalnoj bezbednosti tako što: 1) razmatra pitanja iz oblasti odbrane, unutrašnjih poslova i rada službi bezbednosti; 2) razmatra međusobnu saradnju organa nadležnih za odbranu, organa nadležnih za unutrašnje poslove i službi bezbednosti i njihovu saradnju s drugim nadležnim državnim organima, kao i saradnju sa organima i službama bezbednosti stranih država i međunarodnih organizacija; 3) predlaže nadležnim državnim organima mere za unapređenje nacionalne bezbednosti; 4) razmatra predloge za unapređenje nacionalne bezbednosti koje mu upućuju organi nadležni za odbranu, organi nadležni za unutrašnje poslove, službe bezbednosti i drugi nadležni državni organi; 5) razmatra pitanja iz delokruga organa državne uprave, autonomnih pokrajina, opština, gradova i grada Beograda, koja su značajna za nacionalnu bezbednost, i 6 ) razmatra i druga pitanja koja su značajna za nacionalnu bezbednost.

Osim toga, Savet za nacionalnu bezbednost, u skladu sa istim zakonom, usmerava i usklađuje rad službi bezbednosti kroz razmatranje, davanje mišljenja i donošenje zaključaka vezanih za rad službi bezbednosti. Članovi Saveta su: predsednik Republike; predsednik Vlade; ministar odbrane; ministar unutrašnjih poslova; ministar pravde; načelnik Generalštaba Vojske Srbije, i direktori službi bezbednosti. Savet ima sekretara Saveta, koji učestvuje u radu Saveta bez prava odlučivanja.

Takođe, gore navedenim zakonom, obrazovan je i Biro za koordinaciju rada službi bezbednosti. U skladu sa zakonom, Biro za koordinaciju operativno usklađuje rad službi bezbednosti i izvršava zaključke Saveta za nacionalnu bezbednost, o pitanjima iz svoje nadležnosti. Biro za koordinaciju, posebno obavlja sledeće zadatke, i to: utvrđuje zadatke koji se izvršavaju operativnim usklađivanjem delatnosti službi bezbednosti i službi bezbednosti i drugih državnih organa, i s tim u vezi koordinira njihove aktivnosti; utvrđuje način operativnog usklađivanja u pojedinim slučajevima; osniva mešovite radne grupe za operativne zadatke koji se izvršavaju operativnim usklađivanjem delatnosti i utvrđuje njihove zadatke; analizira rezultate operativnog usklađivanja i o tome po potrebi izveštava Savet, a najmanje jednom u šest meseci. Biro za koordinaciju čine: direktori službi bezbednosti i sekretar Saveta. U radu Biroa za koordinaciju mogu po pozivu da učestvuju: predstavnici Ministarstva spoljnih poslova; direktor policije i načelnici uprava policije; Republički javni tužilac; direktor Uprave carina; rukovodioci drugih državnih organa, organizacija i institucija. 
U skladu sa zakonom, rad službi bezbednosti je pod demokratskom civilnom kontrolom Narodne skupštine, predsednika Republike, Vlade, Saveta za nacionalnu bezbednost, drugih državnih organa i javnosti. S tim u vezi, Narodna skupština obavlja nadzor nad radom službi bezbednosti neposredno i preko nadležnog odbora Narodne skupštine. Posredno ostvaruje nadzor tako što usvaja zakon o službama bezbednosti i celokupnom obaveštajno-bezbednosnom sistemu i obezbeđuje da ga pripadnici službi dosledno sprovode. Neposredan nadzor ostvaruje preko odbora koji formira u tu svrhu. Na osnovu zakona, Odbor naročito: nadzire ustavnost i zakonitost rada službi bezbednosti; nadzire usklađenost rada službi bezbednosti sa strategijom nacionalne bezbednosti, strategijom odbrane i bezbednosno-obaveštajnom politikom Republike Srbije; nadzire poštovanje političke, ideološke i interesne neutralnosti u radu službi bezbednosti; nadzire zakonitost primene posebnih postupaka i mera za tajno prikupljanje podataka; nadzire zakonitost trošenja budžetskih i drugih sredstava za rad; razmatra i usvaja izveštaje o radu službi bezbednosti; razmatra predloge zakona, drugih propisa i opštih akata iz nadležnosti službi bezbednosti; pokreće inicijative i podnosi predloge zakona iz nadležnosti službi, izveštava Narodnu skupštinu o svojim zaključcima i predlozima...

\section{Službe bezbednosti}

U skladu sa članom 4. Zakona o osnovama uređenja službi bezbednosti Republike Srbije, službe bezbednosti su Bezbednosno-informativna agencija, kao posebna organizacija, Vojnobezbednosna agencija i Vojnoobaveštajna agencija, kao organi uprave u sastavu Ministarstva odbrane.

\section{Bezbednosno-informativna agencija}

Bezbednosno-informativna agencija Republike Srbije (BIA) predstavlja samostalnu specijalizovanu vladinu ustanovu zaduženu za vršenje obaveštajnih, kontraobaveštajnih i drugih, zakonom i drugim zakonskim aktima i propisima, poslova bezbednosti.

Prema Zakonu o BIA, kojim je definisan njen delokrug rada, agencija predstavlja autonomno-centralnu obaveštajno-bezbednosnu ustanovu, neposredno podređenu Vladi Republike Srbije, i koja za svoj rad odgovara Narodnoj skupštini i Vladi RS. BIA se u svom radu pridržava načelnih stavova i smernica Vlade RS koji se odnose na bezbednosno-obaveštajnu politiku RS (Savić, 2008:159).

\section{Vojnobezbednosna agencija}

Vojnobezbednosna agencija je organ uprave Ministarstva odbrane Republike Srbije, odnosno resorna vojna kontraobaveštajna služba, čiji je osnovni zadatak da štiti Vojsku Srbije i Ministarstvo odbrane Republike Srbije od špijunsko-subverzivnih delatnosti spoljnih i unutrašnjih nosilaca usmerenih na podrivanje odbrambenih mogućnosti Republike Srbije (Mijalkovski, 2009:247). 
Stupanjem na snagu Zakona o osnovama uređenja službi bezbednosti Republike Srbije 2007. godine, odnosno usvajanja Zakona o Vojnobezbednosnoj i Vojnoobaveštajnoj agenciji iz 2009. godine, sa izmenama iz 2012. godine, uspostavljena je VBA po ustrojstvu po kojem i danas funkcioniše. Ovim zakonom su uređeni nadležnosti, poslovi, zadaci, ovlašćenja, nadzor i kontrola VBA i VOA, saradnja, kao i druga pitanja od značaja za njihov rad.

\section{Vojnoobaveštajna agencija (VOA)}

Vojnoobaveštajna agencija, kao organ uprave Ministarstva odbrane Republike Srbije i relativno samostalna obaveštajna organizacija (resorna), prikuplja, analizira, procenjuje, obrađuje i dostavlja nadležnim vojnim i državnim organima obaveštajne informacije o postojećim i potencijalnim opasnostima, aktivnostima, planovima ili namerama stranih država, i posebno njihovih oružanih snaga, međunarodnih i stranih organizacija, grupa i pojedinaca usmerenih protiv Vojske Srbije, Ministarstva odbrane Srbije, suvereniteta, teritorijalnog integriteta i odbrane Republike Srbije (Mijalkovski, 2009:247).

\section{Obaveštajno-bezbednosni sistem Republike Mađarske}

Kada govorimo o obaveštajno-bezbednosnom sistemu Republike Mađarske, hronološki ćemo navesti nekoliko bitnih činjenica. Naime, raspadom SSSR i Varšavskog ugovora (1991), odnosno krajem hladnog rata, nastupio je period koji je direktno uticao na krupne promene koje su se desile i u Mađarskoj, što se takođe krajem 80-ih godina odrazilo i na bezbednosno-obaveštajni sistem. Imajući u vidu činjenicu da je Mađarska bila članica Varšavskog ugovora od 1955. godine, zamenom komunističkom sistema demokratskim, uspostavila je svestranu i dinamičnu saradnju sa SAD i NATO-om, posebno u redefinisanju svog sektora bezbednosti. Program NATO-a Partnerstvo za mir pristupila je 8. februara 1994. godine, u punopravno članstvo NATO-a primljena je 24. aprila 1999. godine, a 1. maja 2004. godine postala je članica Evropske unije.

Oblast nacionalne bezbednosti i strategija razvoja oružanih snaga su stavljeni pod nadzor Predsednika, Parlamenta i Parlamentarnog saveta za narodnu odbranu, i Vlade (Ministarsko veće), odnosno ministara odbrane, unutrašnjih i spoljnih poslova i dr. S tim u vezi, prvi pravni akt koji je definisao oblast nacionalne bezbednosti bio je Zakon $H$, usvojen 1990. godine, kojim su udareni temelji novog obaveštajno-bezbednosnog sistema Mađarske. Zakonom su osnovane nove institucije i ustanove sistema: 1. Ured za nacionalnu bezbednost; i 2. Informacioni ured - nova obaveštajno-bezbednosna služba, funkcionalno podeljena na vojnu obaveštajnu službu (podređenu ministru odbrane) i civilnu tajnu službu (pod nadzorom ministra bez portfelja u vladi Mađarske). Pored ovih ustanova, obaveštajno-bezbednosni sistem Mađarske još su činili: 3. obaveštajne i bezbednosne organizacije Ministarstva unutrašnjih poslova (Služba bezbednosti, Jedinice nacionalne bezbednosti, i dr); 4. međunarodna odeljenja (obaveštajne institucije) u sastavu drugih institucija; 5 . vojna obaveštajna i kontraobaveštajna služba mađarske armije. Pored Zakona $\mathrm{H}$, još dva dokumenta su suštinski opredelila dalji pravac razvoja mađarskog obaveštajno-bezbednosnog sistema: 1) Osnovni principi nacionalne odbrane Republike 
Mađarske, koje je usvojio Parlament 30. marta 1993. godine i 2) Zakon SH usvojen 1993. godine, kojim su vojna obaveštajna i kontraobaveštajna služba izdvojene iz Generalštaba oružanih snaga i stavljene pod kontrolu ministra odbrane (Savić, 2008:138).

Državna skupština Republike Mađarske donela je Zakon/dekret o službama nacionalne bezbednosti 1995. godine, kojim je utvrđena organizacija i delokrug rada postojećeg obaveštajno-bezbednosnog sistema Republike Mađarske. Prema ovom Zakonu, obaveštajnobezbednosni sistem sačinjavaju sledeće službe za nacionalnu bezbednost: Informacioni ured $(I H)$, kao spoljna obaveštajna služba; Ured za nacionalnu bezbednost (NBH), odnosno služba bezbednosti; Stručna služba za nacionalnu bezbednost (NBSzSz); Vojne službe za nacionalnu bezbednost: a) Vojni izviđački ured (KFH), i b) Ured vojne bezbednosti (KBH) (Savić, 2008:139).

Osim gore navedenog, dana 31. marta 2004. godine, usvojena je i nova Strategija nacionalne bezbednosti Republike Mađarske koja je utvrdila nacionalne bezbednosne interese Republike Mađarske: očuvanje suvereniteta, teritorijalnog integriteta, ostvarivanje privrednog, društvenog i kulturnog razvoja zemlje, održavanje međunarodnog mira i bezbednosti, proširivanje i produbljivanje integracije ostvarene u okvirima Evropske Unije.

$\mathrm{Na}$ osnovu Odluke o radu službi nacionalne bezbednosti rukovođenje i kontrola rada nacionalnih civilnih obaveštajnih i bezbednosnih ustanova poverena je Vladi, odnosno ministru koga Vlada odredi, pri čemu to ne može biti aktuelni ministar unutrašnjih poslova, odbrane i pravde. Prema istoj odluci, vojnim službama nacionalne bezbednosti rukovodi ministar odbrane. Parlamentarna kontrola rada službi nacionalne bezbednosti poverena je Nacionalnoj skupštini u saradnji sa Odborom za nacionalnu bezbednost $i$ Odborom za odbranu (Savić, 2008:139).

\section{Analiza obaveštajno-bezbednosnog sistema Republike Srbije i Republike Mađarske}

U ovom delu rada urađena je komparativna analiza nacionalnih obaveštajno-bezbednosnih sistema Republike Srbije i Republike Mađarske, posebno u pogledu sličnosti i razlika, kako u normativnopravnoj oblasti, tako i u organizaciono-funkcionalnim strukturnim elementima službi bezbednosti. Sigurno je da bi se, pri dubljoj studiji, i u uslovima sveobuhvatne i detaljne analize bezbednosnog sistema jedne zemlje, u poređenju sa sistemima drugih zemalja, mogle uočiti brojne sličnosti i razlike, kao i razne specifičnosti. lako su često sadržina i ciljevi pojedinih službi po spoljašnjim oznakama i manifestacijama različiti, oni se po suštini i metodima rada koji se primenjuju, uopšte međusobno ne razlikuju i imaju mnogo zajedničkog. Na to ukazuje i detaljna komparativna analiza koju ćemo ovom prilikom izložiti, nacionalnih obaveštajno-bezbednosnih sistema Republike Srbije i Republike Mađarske. Iz tih razloga pokušaćemo da na osnovu raspoloživih podataka prezentujemo jedan komparativni (uporedni) pregled obaveštajno-bezbednosnih sistema sa stanovišta nacionalne bezbednosti.

Kada je u pitanju mesto i uloga obaveštajno-bezbednosnog sistema Republike Srbije i Republike Mađarske, oni su definisani zakonima o službama bezbednosti, koji su usklađeni sa najvišim pravnim aktima, Ustavom i Strategijom nacionalne bezbednosti. 
Analizirajući normativno-pravni okvir, koji se odnosi na obaveštajno-bezbednosni sistem te dve države, uočava se razlika u hronologiji donošenja zakona i drugih propisa, odnosno razlika u redosledu usvajanja normativno-pravnih akata iz oblasti bezbednosti. S tim u vezi, u Republici Mađarskoj je prvo donet zakon, zatim Ustav i na kraju Strategija nacionalne bezbednosti, gde je ispoštovan redosled donošenja pravnih akata po određenoj hronologija, imajući u vidu da je pre donošenja zakona 1995. godine, na snazi bio redefinisan Ustav i Strategija nacionalne bezbednosti. Nakon ulaska Republike Mađarske u NATO i EU, očekivano je bilo usvajanje novog Ustava i Strategije nacionalne bezbednosti, pa nakon toga usvajanje novog zakona o obaveštajno-bezbednosnom sistemu.

S druge strane, u Republici Srbiji nije poštovana hronologija usvajanja ovih normativnih akata. Tako je novi Ustav donet 2006. godine, Strategija nacionalne bezbednosti 2009. godine, a pre nje, 2007. godine donet je Zakon o službama bezbednosti. Zakon o vojnim službama proistekao je iz Zakona o službama bezbednosti i usvojen je 2009. godine, sa izmenama iz 2012. godine, dok je Zakon o BIA usvojen još 2002. godine, a novi donet 2018. godine. Na osnovu toga, može se steći utisak da je Zakon o službama bezbednosti pisan na osnovu Zakona o BIA, uzimajući u obzir da je on više pravne snage od Zakona o BIA.

Takođe, u Republici Srbiji postoji „opšti” zakon koji definiše ovu oblast i dva posebna zakona, koji se odnose na vojne službe, VBA i VOA i civilnu službu (BIA), dok u Republici Mađarskoj ne postoji zakon o vojnim službama, već je sve definisano u jednom zakonu. Osim toga, u mađarskom zakonu o službama bezbednosti, precizno i detaljno je navedeno praktično sve, kao što je: organizacija, ovlašćenja, nadzor i kontrola. U Srbiji je to urađeno samo u Zakonu o vojnim službama bezbednosti. Analizom Strategija nacionalnih bezbednosti, takođe postoje razlike, tako da u srpskoj strategiji precizno su navedene obaveštajno-bezbednosne službe koje funkcionišu kao državne organizacije, što povlači za sobom činjenicu, da u slučaju potrebe formiranja nove službe ili restrukturiranja postojećih, praktično mora da se menja i postojeća Strategija nacionalne bezbednosti. Navodimo još jednu razliku, a to je definisanje stepena ugroženosti nacionalne bezbednosti. $U$ srpskoj strategiji navodi se da postoje značajni rizici i pretnje, dok je u mađarskoj stepen ugroženosti ocenjen kao mali. Daljom analizom, uočava se značajna razlika u definisanju mesta i uloge stranih faktora koji utiču na nacionalnu bezbednost. Dok mađarska strategija navodi da oni „crpe” bezbednost iz svog članstva u NATO-u i EU, u srpskoj strategiji se navodi da je međunarodni faktor zastupljen kroz saradnju.

Kada je u pitanju analiza organizacionih razlika i sličnosti, zajedničko za obe zemlje je da imaju decentralizovan ili resorni obaveštajno-bezbednosni sistem, koji čine civilne i vojne obaveštajno-bezbednosne službe. Danas u Republici Mađarskoj postoji šest službi, pet civilnih i jedna vojna. Osnovna specifičnost mađarskog obaveštajno-bezbednosnog sistema u odnosu na Republiku Srbiju, jeste ta što je premijer Orban, 2010. godine, formirao novu službu, Službu za nacionalnu odbranu, koja između ostalog ima zadatak kontrole rada svih ostalih službi u zemlji, i koja je direktno odgovorna premijeru, pa mnogi ocenjuju da je ovo „partijska služba namenjena za potpunu kontrolu svih političkih i drugih subjekata u zemlji”.

U Republici Srbiji deluju jedna civilna i dve vojne službe. Republika Mađarska, za razliku od Republike Srbije, objedinila je vojnu obaveštajnu i kontraobaveštajnu službu u jednu službu bezbednosti.

Analizom broja službi, kao i analizom strategijskih odredbi zemalja u smislu definisanja bezbednosnih izazova, rizika i pretnji (gde se smatra da je Republika Srbija ugroženija), primećuje se da Republika Mađarska ima više službi od Republike Srbije. Međutim, broj 
službi sam po sebi ništa ne znači, ali ako uporedimo broj pripadnika civilnih službi Republike Srbije i Republike Mađarske (po nekim procenama u Srbiji je u BIA zaposleno duplo manje nego u mađarskim službama - nešto više od 4.000 lica), dolazimo do zaključka da broj zaposlenih u Republici Srbiji nije adekvatan u odnosu na stepen ugroženosti zemlje, uzimajući kao parametar Republiku Mađarsku. Što se tiče vojnih službi situacija je slična. Naime, broj pripadnika vojnih službi u Republici Srbiji se tokom reformi smanjivao, što nije svojstveno ostalim zemljama koje su bile u tranziciji. Ako kao parametar opet uzmemo Republiku Mađarsku, prema poslednjim dostupnim podacima, broj pripadnika prvo dve vojne, a zatim objedinjene jedne vojne službe, iz godine u godinu se povećavao. lako je u Strategijskom pregledu odbrane iz 2007. godine, bilo planirano da se u Republici Srbiji objedine VBA i VOA u jednu agenciju, od tog predloga se odustalo tako da za sada samo u Republici Srbiji u sastavu Ministarstva odbrane postoje dve agencije (Petrović, 2011:6).

Treba napomenuti da je Republika Mađarska veoma dobro pokrivena, u organizacionom smislu, po pitanju obaveštajne i kontraobaveštajne delatnosti, tako da postoji posebna civilna obaveštajna služba. Za razliku od Mađarske, u Srbiji nije takva situacija: obaveštajnu i kontraobaveštajnu delatnost u civilnom sektoru obavlja BIA. Bitno je napomenuti da je Zakonom iz 2007. godine, tadašnja obaveštajna služba Ministarstva spoljnih poslova (SID) ukinuta, pa je tu ulogu preuzela BIA.

Takođe, bitna razlika u organizacionom smislu predstavlja uređenje sastava za operativnotehničke mere. Dok su to u Republici Mađarskoj posebne nezavisne organizacijske celine koje pružaju usluge službama (u Mađarskoj ima i ulogu operativne službe što joj daje posebnu težinu), u Republici Srbiji su ti sastavi sastavni deo svake službe. Rešenje koje je primenjeno u Republici Mađarskoj obezbeđuje manje troškove, bolju koordinaciju i kontrolu. U delu koji se tiče primene posebnih mera i postupaka, bitna razlika je u nivou sudske vlasti, koji odobrava posebne mere. U Republici Srbiji je to predsednik Kasacionog suda (odnosno sudija koga on odredi), dok je u Republici Mađarskoj niža instanca, predsednik okružnog suda (odnosno sudija koga on odredi). U Mađarskoj je to opravdano činjenicom da je okružni sudija više upoznat sa problemom na koji se odnosi primena mera od položajno višeg sudije, što za posledicu ima lakše dobijanje odobrenja za primenu mera. Postoji razlika i u pogledu trajanja mera. Primena mera u Republici Srbiji traje šest meseci, što može da se produži na još šest meseci, u Mađarsko tri plus tri meseca. U odnosu na same mere, ne postoje značajne razlike.

Koordinacija rada službi bezbednosti u Republici Srbiji praktično je rešena na isti način, postojanjem tela koji obavlja tu dužnost (Biro za koordinaciju). U Republici Mađarskoj ne postoji takvo telo već koordinaciju praktično sprovodi predsednik Vlade kroz rad sa ministrima kojima su službe potčinjene, ali zato u strukturi svake službe postoji posebna organizaciona jedinica čiji je zadatak upravo koordinacija sa ostalim službama.

Kao i u većini zemalja, demokratsku civilnu kontrolu i nadzor nad radom službi bezbednosti, i u Srbiji i u Mađarskoj, obavljaju parlament, izvršna vlast, sudski organi, saveti za nacionalnu bezbednost, revizorske agencije, ombudsman i institucije građanskog društva - nevladine organizacije, mediji i javnost. Od svih pomenutih institucija, parlament ima, zajedno sa svojim odborima za bezbednosna pitanja ili specijalizovanim kontrolnim telima, centralnu ulogu u kontroli i nadzoru nad radom službi bezbednosti u obe zemlje. U Republici Mađarskoj parlamentarnu kontrolu i nadzor ostvaruju dva odbora i to Odbor za odbranu i primenu zakona i Odbor za nacionalnu bezbednost, dok u Srbiji Narodna skupština nadzor ostvaruje neposredno i posredstvom Odbora za kontrolu službi bezbednosti. 


\section{Zaključak}

Na kraju, na osnovu raspoloživih podataka, u radu smo prezentovali jedan komparativni (uporedni) pregled obaveštajno-bezbednosnih sistema sa stanovišta nacionalne bezbednosti, Republike Srbije i Republike Mađarske, posebno u pogledu sličnosti i razlika, kako u normativno-pravnoj oblasti, tako i u organizaciono-funkcionalnim strukturnim elementima službi bezbednosti. S tim u vezi, reforma obaveštajno-bezbednosnog sistema u Republici Srbiji i Republici Mađarskoj, započeta je nakon političkih promena, krajem prošlog, odnosno u prvoj deceniji XXI veka. Te reforme, u obe zemlje, uslovila su dva faktora, i to: prvo, obezbeđivanje političke volje, odnosno konsenzusa, da se uđe u proces reforme; i drugo, politička odluka da se pristupi Evropskoj uniji i evroatlantskim integracijama. Ova dva faktora suštinski su opredeljivala početak reformi, njen tok i brzinu sprovođenja.

Na osnovu analize, možemo konstatovati da su u Republici Mađarskoj, dosta brzo sprovedene političke promene, dok su u Republici Srbiji promene intenzivirane tek nakon 2000. godine, tako da se brzina reformi odrazila i na obaveštajno-bezbednosni sistem. Možemo reći da je Republika Mađarska odmah nakon napuštanja Varšavskog ugovora započela proces reformi obaveštajno-bezbednosnog sistema, dok su reforme u Republici Srbiji započete kasnije, gde su primenjena dva različita pristupa reformama, što se odrazilo i na dužinu njihovog trajanja. Reforma obaveštajno-bezbednosnog sistema u obe države, svodila se na dva ključna pitanja: na stvaranje adekvatnog normativno pravnog okvira, i na izgradnju efikasnog sistema kontrole i nadzora. Republika Mađarska je sprovela reformu obaveštajno-bezbednosnog sistema uz određene poteškoće, ali uz značajnu podršku i pomoć EU i NATO-a, čija je članica. Za razliku od nje, Republika Srbija, koja nije članica evroatlantskih integracija, uspela je da reformiše taj sektor i učini ga kompatibilnim sa savremenim obaveštajno-bezbednosnim sistemima, pre svega sa zemljama EU. Reformišući ovaj sektor Republika Mađarska se, izvukavši pouke iz zloupotreba službi iz doba socijalizma, opredelila za decentralizaciju obaveštajno-bezbednosnog sektora i formiranje više manjih službi sa jasno određenim delokrugom. Formiranjem više manjih službi od pripadnika starih službi, koje su potčinjene različitim organima izvršne vlasti, Republika Mađarska je obezbedila bolju kontrolu tog izuzetno osetljivog sektora.

Kada je u pitanju reforma u Republici Srbiji odvijala se u dva odvojena pravca i to: u civilnom i u vojnom sektoru. U vojnom sektoru reforma je gotovo potpuno zaokružena stvaranjem dve agencije, što je pratilo i usvajanje zakona koji reguliše njihov rad po svim savremenim načelima. Reforma u vojnom sektoru u pojedinim segmentima, iako sprovođena samostalno i na osnovu iskustava drugih zemalja, ima bolja i transparentnija rešenja nego što su rešenja u Republici Mađarskoj. Takođe, suštinska razlika predstavlja činjenica da su u Republici Mađarskoj vojna obaveštajna i kontraobaveštajna služba objedinjene u jednu službu, što u Republici Srbiji nije slučaj, iako je u prethodnom periodu bilo najava objedinjavanja službi. Slična razmišljanja možemo i danas čuti od pojedinih predstavnika zakonodavne vlasti. S druge strane, možemo reći da je reforma u civilnom sektoru detaljnije započeta donošenjem Zakona o BIA 2002. godine. Taj zakon je doneo suštinsku reformu u organizacionom smislu, odnosno izlaskom BIA iz resora Ministarstva unutrašnjih poslova, dok su u Republici Mađarskoj dve službe, i to: Ured za nacionalnu bezbednost i Stručna služba za nacionalnu bezbednost, nakon ulaska u NATO-a i EU, 
vraćene pod jurisdikciju Ministarstva unutrašnjih poslova. Na osnovu toga, postavlja se pitanje da li se izlaskom BIA iz Ministarstva unutrašnjih poslova suštinski nešto dobilo? To potvrđuje i činjenica da su pripadnici BIA, prema Zakonu iz 2002. godine, i pored izlaska iz Ministarstva unutrašnjih poslova zadržali policijska ovlašćenja.

Takođe, uočljivo je, da je reformom i donošenjem zakona iz 2007. godine, Republika Srbija se obavezala da u ovoj oblasti jasnije i bolje definiše sektor bezbednosti, odnosno da treba doneti novi zakon o BIA, koji je tek donet ove godine. U međuvremenu, usvojeni su i Ustav i Strategija nacionalne bezbednosti, a Zakon o BIA nije bio promenjen. Osim toga, Zakonom iz 2007. godine i prestankom postojanja civilne obaveštajne službe u Ministarstvu spoljnih poslova (SID), praktično je nastao „vakuum” u obaveštajnom delovanju civilnih struktura, odnosno tu funkciju je preuzela BIA.

$\mathrm{Na}$ osnovu iznete analize i na osnovu navedenih činjenica, navodi nas na zaključak da je obaveštajno-bezbednosni sistem Republike Srbije delimično kompatibilan sa zemljom u okruženju, koja je članica Evropske unije, kao i da Srbiji u procesu priključenja EU i približavanju da postane punopravna članica, predstoji još reformi u ovoj oblasti. Preciznije rečeno, vojni deo obaveštajno-bezbednosnog sistema je gotovo u većem delu kompatibilan sa standardima EU u ovoj oblasti, dok civilnom delu tek predstoje kako organizacione, tako i normativno-pravne reforme, odnosno usklađivanje sa propisima EU. Takođe, tendencija spajanja vojne obaveštajne i kontraobaveštajne komponente u jednu objedinjenu službu, zahteva detaljnu analizu i procenu mogućih prednosti ali i nedostataka koji taj koncept nosi. Iskustva dobijena u nekim ličnim kontaktima sa predstavnicima vojnih službi Republike Mađarske, ukazuju na to da se osim finansijskih efekata nije mnogo dobilo na kvalitetu rada u odnosu na period kada su službe bile razdvojene.

I na kraju, ova komparativna analiza postojećih iskustava i sadašnje prakse, može doprineti razmišljanju u donošenju konačnih odluka o modernom i savremenom obaveštajno-bezbednosnom sistemu države, usklađenog sa standardima Evropske unije, u cilju njegove efektivnosti i efikasnosti. Maksimalna funkcionalnost i uređenost obaveštajnobezbednosnog sistema Republike Srbije, sasvim sigurno omogućava adekvatno suprotstavljanje savremenim izazovima, rizicima i pretnjama bezbednosti, u skladu sa nacionalnom bezbednošću. Naravno, kao i svaki drugi društveni sistem, tako i ovaj sistem zahteva permanentno praćenje savremenih tokova i dostignuća, kao i unapređenje svoje organizacijske i normativno-pravne oblasti, u skladu sa nacionalnim interesima države.

\section{Literatura}

[1] Andreja Savić, Savremeni sistemi bezbednosti (Beograd: Akademija za diplomatiju i bezbednost, 2008).

[2] Dejan Milenković, Slobodan Koprivica, Vladimir Todorić, Kontrola službi bezbednosti (Beograd: Centar za novu politiku, 2011).

[3] Zoran Dragišić, Sistem nacionalne bezbednosti Republike Srbije, (Beograd: Fakultet bezbednosti, 2011).

[4] Zakon o osnovama uređenja službi bezbednosti Republike Srbije („Službeni glasnik RS“, broj 116/2007).

[5] Zakon o Bezbednosno-informativnoj agenciji („Službeni glasnik RS“, broj 42/2002, 111/2009, 65/2014-odluka US, 66/2014 i 36/2018). 
[6] Zakon o Vojnobezbednosnoj agenciji i Vojnoobaveštajnoj agenciji („Službeni glasnik RS“ br. 88/2009).

[7] Krivični zakonik, (Službeni glasnik Republike Srbije”, br. 85/2005, 88/2005, 107/2005, 72/2009, 111/2009 i 121/2012).

[8] Ljubomir Stajić, Osnovi sistema bezbednosti (Novi Sad: Pravni fakultet, 2011).

[9] Ljubomir Stajić, Kontrola policije i službi bezbednosti (Novi Sad: Pravni fakultet, 2012).

[10] Milan Milošević, Sistem državne bezbednosti (Beograd: Policijska akademija, 2001). 2009).

[11] Milan Mijalkovski, Obaveštajne i bezbednosne službe (Beograd: Fakultet bezbednosti,

[12] Milan Tišma, Odbrana i bezbednost u Mađarskom Ustavu, Vojno delo, vol. 63, broj 3, (2011).

[13] Naj Džozef, Kako razumevati međunarodne sukobe (Beograd: Stubovi kulture, 2006).

[14] Obren Đorđević, Leksikon bezbednosti (Beograd: Partizanska knjiga, 1986).

[15] Predrag Petrović, Nadzor službi bezbednosti na Zapadnom Balkanu: Slučaj Srbija, (Beograd: Beogradski centar za bezbednosnu politiku, 2011).

[16] Strategiji nacionalne bezbednosti Republike Srbije, (Beograd: 2009).

[17] Stanimir Đukić, Osnovi bezbednosti i sistem bezbednosti u strategiji nacionalne bezbednosti, Vojno delo, vol. 69, broj 7, (2017).

[18] Uredba o načinu evidentiranja, obrade, čuvanja, korišćenja, zaštite i dostavljanja drugim nadležnim državnim organima informacija i dokumenata o poslovima iz nadležnosti BIA, ("Službeni glasnik Republike Srbije“, br. 68/02). 